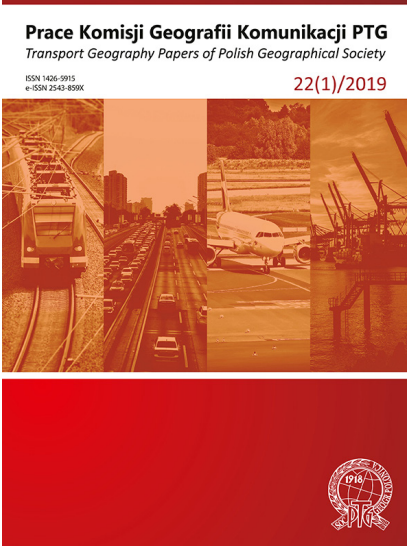

Transport Geography Papers of Polish Geographical Society

$2019,22(1), 22-30$

DOI 10.4467/2543859XPKG.19.004.10924

Received: 17.01 .2019

Received in revised form: 05.03.2019

Accepted: 08.03 .2019

Published: 29.03 .2019

\title{
TIME DEVIATIONS IN THE OPERATION OF PUBLIC TRANSPORT PROVIDING ACCESS TO SELECTED SERVICES IN THE CITY OF SZCZECIN
}

\author{
Odchylenia czasowe w funkcjonowaniu transportu publicznego do wybranych \\ usług w Szczecinie
}

\author{
Sławomir Goliszek \\ Institute of Geography and Spatial Organization Polish Academy of Sciences, Twarda 51/55, 00-818 Warsaw, Poland \\ e-mail: sgoliszek@twarda.pan.pl
}

\section{Citation:}

Goliszek S., 2019, Time deviations in the operation of public transport providing access to selected services in the city of Szczecin, Prace Komisji Geografii Komunikacji PTG, 22(1), 22-30.

\begin{abstract}
The article presents issues related to public transport time accessibility to some selected services, including indoor swimming pools, cinemas, hospitals and shopping centres. In order to measure the above-mentioned accessibility the short distance method was used in the following time periods: 7:00-9:00 am for the hospitals; 5:00-7:00 pm for the shopping centres; 6:00-8:00 pm for the cinemas and 6:00-8:00 pm for the swimming pools. For each time period the measures were taken every 15 minutes. The main purpose of the article is to determine temporal accessibility for various purposes, the number of people living at a certain time distance and the diversity of accessibility by public transport. The public transport accessibility to the selected services indicates areas where the accessibility is limited. Time deviations in the operation of the public transport were calculated for all the selected time periods. The results of both measurements and calculations are presented in graphic form. Moreover, the graph includes the number of Szczecin citizens living in different time accessibility areas and in places with the highest time deviations.
\end{abstract}

Key words: GTFS, time deviations, public transport 


\section{Introduction}

The issues of time accessibility and travel times have been studied by scholars for many years. At the beginning some basic spatial relations in daily commuting were analysed. It is believed that the first time accessibility map was created by F. Galton (1881). A more sophisticated method of research was proposed by W. Isard (1954) and W. G. Hansen (1959) - it was the potential transport accessibility method. With time, some Polish researchers have also become interested in the time accessibility issue. The potential accessibility allows to analyse spatial relations based on the gravity method what means that each and every travel destination exerts greater or lesser impact on other travel sources (Chojnicki, 1966; Ingram, 1971). Since the time when the potential method was introduced, methods of researching transport accessibility have evolved, yet still the simplest ones, time and cumulative accessibility, are the most frequently used research methods (Kubijowicz, 1923; Vasiliev, 1997).

For the last several dozen years more and more researchers have been into public transport accessibility (Podolski, 1977). The researchers pay attention to the fact that the number of public services is still growing, yet the number of passengers is not. It is a significant problem as using private cars in everyday commuting results in high traffic congestion in cities. What is more, during the last few years there have been several publications addressing the issue of public transport, including ones on improving its operation by developing the infrastructure (Goliszek, 2014a; Goliszek, 2014b; Goliszek, Połom, 2016a; Goliszek, Rogalski, 2014). In Poland numerous infrastructural projects have been implemented thanks to the EU funds (Bul, Resiński, 2014; Kołoś, 2007; Zalewska, 2016). Also in works on public transport, attention is paid to access to public transport, which plays an important role in the lives of residents of large and medium-sized cities (Korczyński, 2019). Most often those projects were limited to purchasing new rolling stock or, in few cases, to modernising or constructing new tram or underground lines (Beister et al., 2015; Gadziński, Radzimski, 2015; Goliszek, Połom, 2016c; Kołoś, Taczanowski, 2016a; Kołoś, Taczanowski, 2016b), what can be served by the integration of bus and railway stations in the city (Jurkowski, 2018). Before the decision to build or modernize public transport, traffic tests are carried out, during which the flow of people in different directions and at different times of the day is checked using different types of transport (Gadziński, 2018; Radzimski, Gadziński, 2019). When evaluating projects of public transport development, the GTFS data format (General Transit Feed Specification; Delmelle, Casas, 2012) is substan- tially helpful and thanks to this format some new publications on public transport accessibility to different destinations have emerged lately. The researchers used the GTFS data to measure time travels to shops (Widener et al., 2017), shopping centres (Farber et al., 2014), medical centres (Neutens, 2015), cultural and education facilities (Allen, 2019; Martínez-Jiménez, Salinas-Pérez, 2019) as well as to analyse commuting times (Goliszek, 2017a). The analysis based on the GTFS data may be very detailed as travel times may be determined with an accuracy of one minute. However, this format also has some disadvantages and limitations that have to be taken under consideration - some researchers point out large inequalities in access to means of public transport (El-Geneidy et al., 2015; El-Geneidy et al., 2016). The GTFS data do not reflect real-time travel periods, only the ones indicated by timetables which do not include delays resulting from traffic congestion (Allen, 2019; Allen, Farber, 2019; Wessel et al., 2017; Wessel, Widener, 2016). Yet, a public transport model based on the GTFS data allows to compare data for many different cities publishing their public transport timetables in this format (Poelman, Dijkstra, 2015).

Transport accessibility is shaped by the so-called transport components (Geurs, Ritsema van Eck, 2001; Geurs, van Wee, 2004). They are as follows: transport, spatial, time and individual (Goliszek, 2018). In this article, the author focuses on time accessibility, spatial component: location of travel sources and destinations, time component: departure times, transport component: collective transport.

\section{Case study and data}

Szczecin is the capital of Zachodniopomorskie (West Pomeranian) Voivodeship situated in the north-western part of Poland. It has a population of approximately 400 thousand. Data on the city population was published by the City Hall. The population data has been gathered for 1869 census areas and it was possible to assess accurately how many people actually live in areas for which public transport accessibility was calculated. Both the GIS technology and GTFS data have allowed to carry on detailed transport studies (Burdziej, 2016). The GTFS format has already been used by the author and other scholars to conduct comparative research on public transport systems in different European cities (Goch et al., 2018; Goliszek, 2017a; Goliszek, Połom, 2016b; Poelman, Dijkstra, 2015; Stępniak, Goliszek, 2017; Stępniak et al., 2019). The GTFS data published by the company managing urban transport in Szczecin allows to create models based on the timetables and road network (on the basis of Open Street Map). 
The public transport network in Szczecin is presented in figure 1 (on the right). On the left-hand side of figure 1 there are locations of the selected facilities: indoor swimming pools, shopping centres, cinemas and hospitals. For easier orientation on the maps of urban space, the boundaries of districts have been added: Zachód, Prawobrzeże, Północ, Śródmieście and estates: ArkońskieNiemierzyn, Bukowe-Klęskowo, Bukowo, Centrum, Dąbie, Drzetowo-Grabowo, Głębokie-Pilchowo, Golęcino-Gocław, Gumieńce, Kijewo, KrzekowoBezrzecze, Łękno, Majowe, Międzyodrze-Wyspa Pucka, Niebuszewo, Niebuszewo-Bolinko, Nowe Miasto, Osów, Płonia-Śmierdnica-Jezierzyce, Podjuchy, Pogodno, Pomorzany, Skolwin, Słoneczne, Stare Miasto, Stołczyn, Śródmieście-Północ, ŚródmieścieZachód, Świerczewo, Turzyn, Warszewo, WielgowoSławociesze-Zdunowo, Załom-Kasztanowe, Zawadzkiego-Klonowica, Zdroje, Żelechowa, Żydowce-Klucz (Fig. 1). service (Allen, 2018). The analysis of travel times concerned 15-minutes periods at different times of the day, depending on the service type. For the hospitals it was between 7:00 and 9:00 am; for the shopping centres - 5:00-7:00 pm; for the cinemas and swimming pools it was between 6:00 and 8:00 pm. The average travel time deviation was calculated on the basis on data regarding the shortest and the longest travel time to a particular service facility. The number of people in a certain age group was added to the fastest travel times. Similar calculations were done for the areas where some time deviations had been identified. The age groups were as follows: for the hospitals - all citizens; for the indoor swimming pools - 7-65 years; for the shopping centres $-15+$; for the cinemas - 16-65 years. All the results were accumulated to $100 \%$ and divided into time periods. The time accessibility periods (0-60 minutes) were delimited with an accuracy of 5 minutes. The last period comprise areas where the time accessibility to a particular

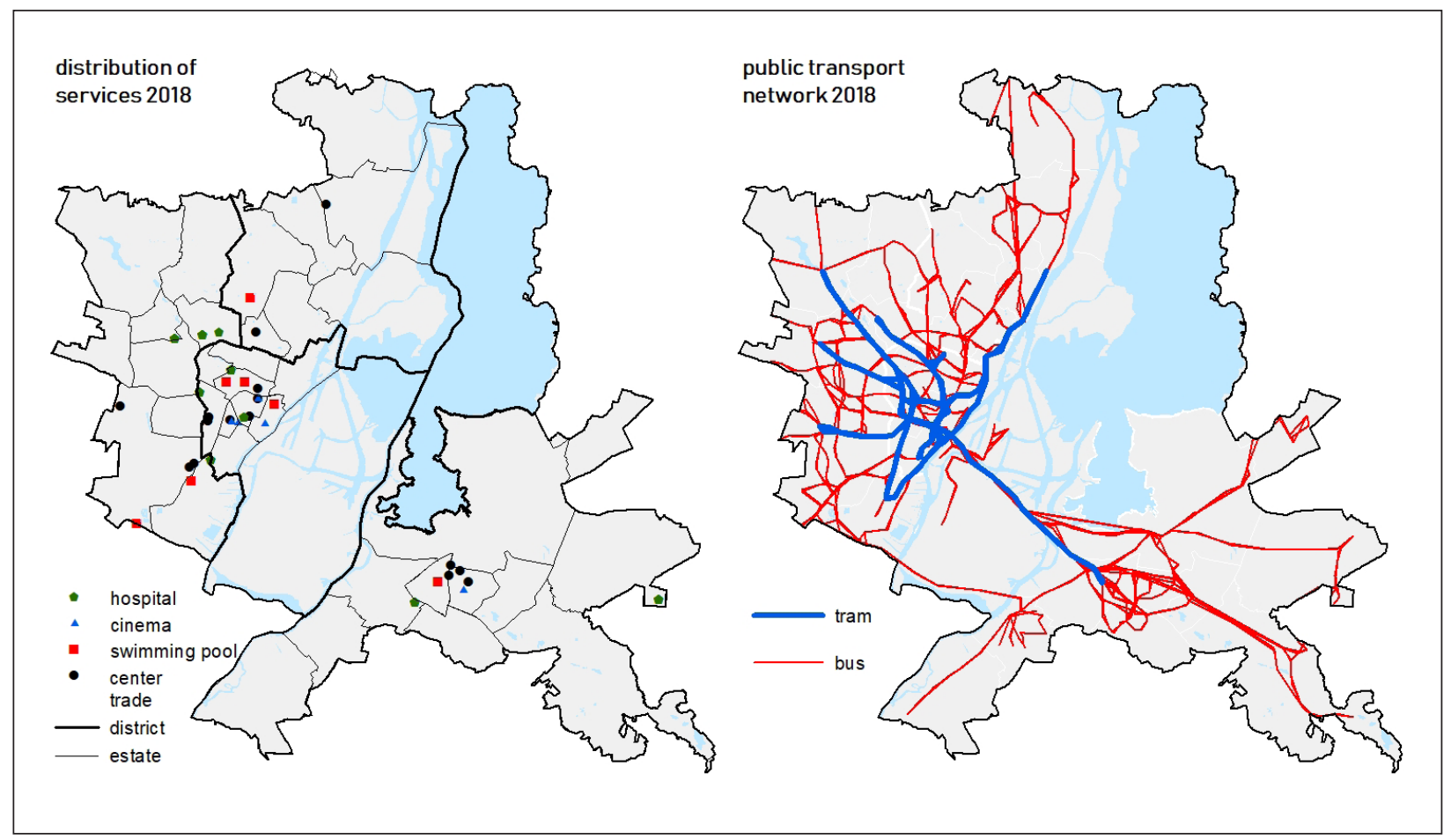

Fig. 1. Location of services and the boundaries of districts and housing estates (left side) and public transport network (right side).

Source: own elaboration.

\section{Research methodology}

The research methodology applied to assess accessibility to the selected services in Szczecin is based on the idea of time accessibility to a given place, a method of the so-called shortest distance to a selected service facility exceeds 60 minutes. The time deviations (from 0 to 14 minutes) for the selected times of the day were delimited with an accuracy of 2 minutes along with the number of citizens living in the areas where the deviation is higher than 14 minutes. 


\section{Time accessibility to the selected services}

The map depicting time accessibility to the indoor swimming pools in Szczecin indicates areas with better or worse accessibility by the means of public transport. The areas in the northern part of Północ district of Szczecin have the worst time accessibility to the indoor swimming pools. In the southern part of Zachód district the accessibility to the indoor swimming pools can be assessed as good, in the northern part of this district the situation is a bit worse. In the central part of Prawobrzeże district the accessibility to the indoor swimming pools is also satisfactory while the peripheral parts of the same district have significantly lower time accessibility to such sport facilities. Densely populated Śródmieście, located in the city centre, is a district with the highest time accessibility to the indoor swimming pools. Slightly lower accessibility was identified in the industrial part of this district, it is also less densely populated.

Time accessibility to the cinemas in Szczecin varies significantly when analysing particular districts of the city. Only in two of them - Śródmieście, where most of the cinemas are located, and Północ the accessibility can be assessed as good. Zachód district can be divided into its northern part with low accessibility and southern one having slightly better time accessibility to the cinemas. In Prawobrzeże time accessibility to the cinemas is similar to the swimming pools accessibility - better in the central part of the district and worse in the peripheral areas (Fig. 2).

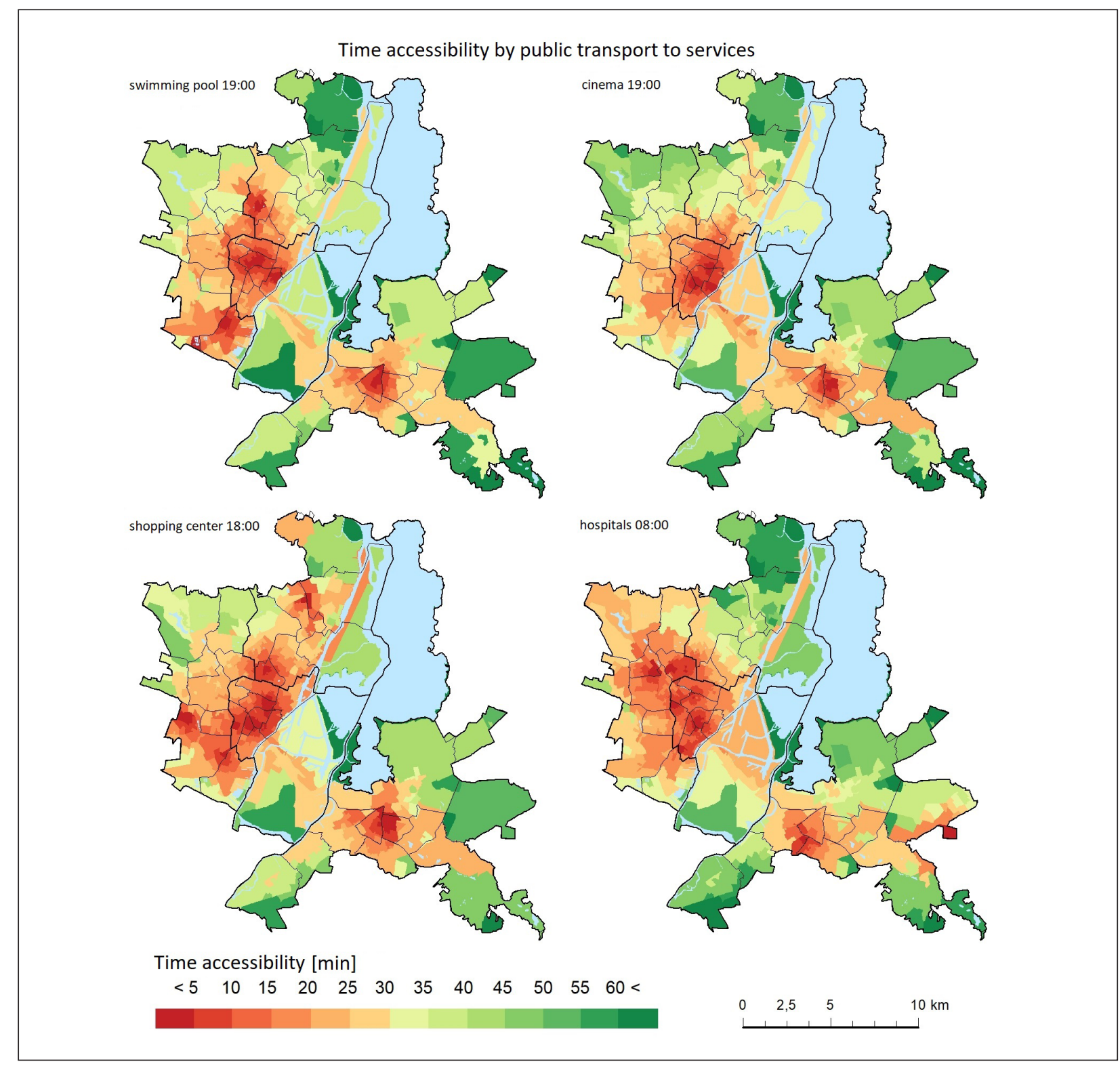

Fig. 2. Time accessibility to selected services in Szczecin.

Source: own elaboration. 
Time accessibility to the shopping centres is more spatially diverse than the accessibility to other selected service facilities. In Prawobrzeże the best accessibility is in the district centre and it drops towards the peripheral areas. The southern part of Zachód district has better time accessibility to the shopping centres than its northern part. The central part of the district has currently good accessibility, yet it is decreasing fast what is a result of linear course of the public transport system towards the city centre. The central part of Śródmieście district has the best time accessibility to the shopping centres, the accessibility is slightly lower in the industrial part. It is illustrated in figure 2.

Północ district has the worst time accessibility to the hospitals. In Zachód district the accessibility can be assessed as relatively good. When it comes to Prawobrzeże, the central and eastern parts have good time accessibility while in the peripheral areas travel times to the hospital are longer. The best time accessibility to the hospitals is in Śródmieście, in its access to the hospitals and swimming pools. Those are places which we usually visit less often. The smallest percentage of Szczecin citizens is present in the time accessibility to the cinemas. Both cinemas and indoor swimming pools are places which people visit less often and their location is not that important in the context of every-day life. The most important observation made on the basis of this graph is the fact that approximately $90 \%$ of people has a chance to get to a selected service facility within 30 minutes using the means of public transport (Fig. 3.).

\section{Time deviations}

The highest time deviations in public transport accessibility to the indoor swimming pools between 6:00 and 8:00 pm are observed in the northern part of Północ district. Similar significant deviations, yet concerning a much larger area, have been recorded for the eastern and the south-western parts of Prawobrzeże. In Zachód district time deviations have

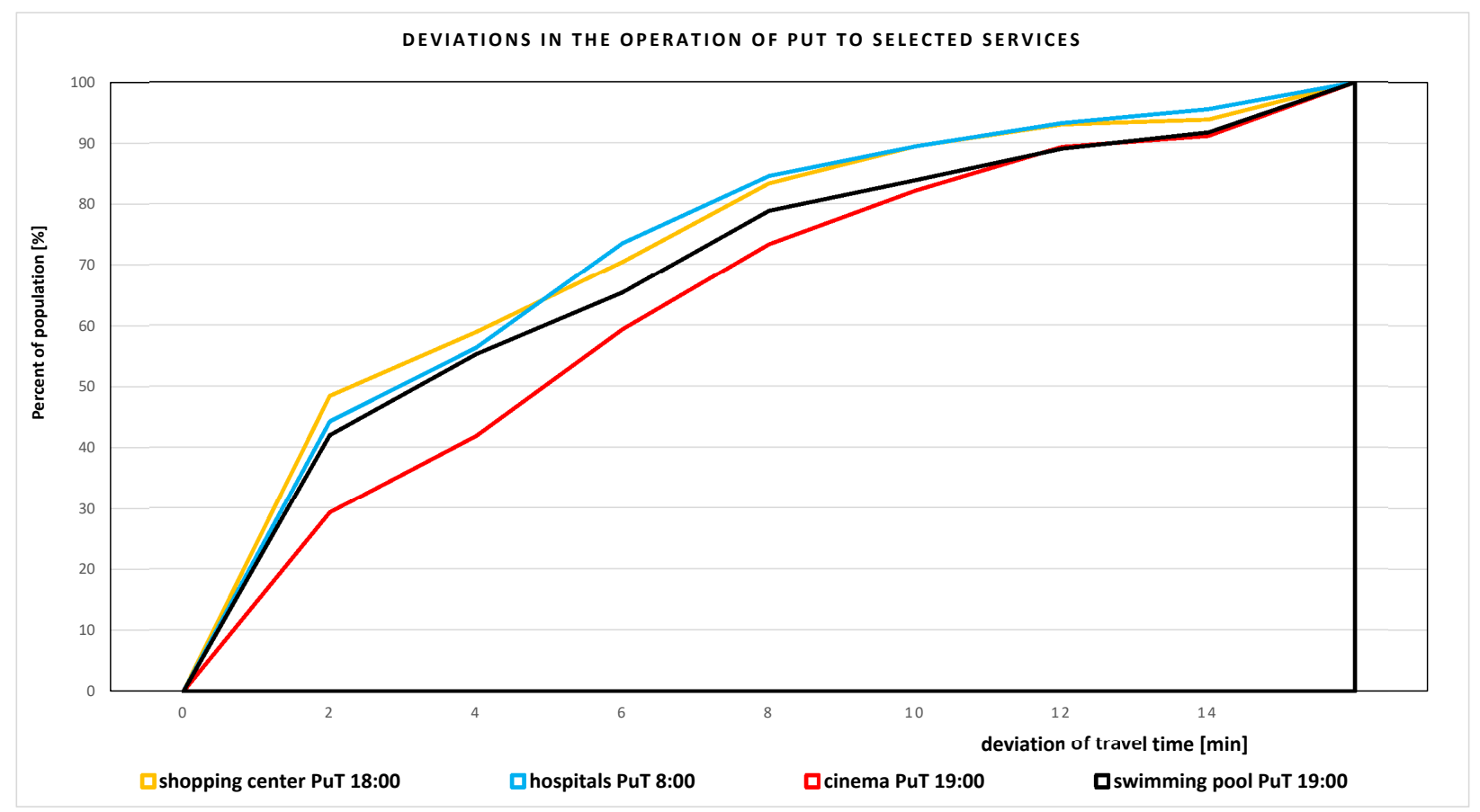

Fig. 3. Sum of population in the selected age and travel time to selected servants.

Source: own elaboration.

residential part. In the industrial part, located near the allotments, the accessibility is lower.

The shopping centres are facilities with the best public transport time accessibility as they are usually located in densely populated areas. Thus, in such locations operation of the urban public transport system is profitable. It is worth paying attention to the fact that a similar percentage of people have similar gained a medium level. They are more visible in the northern part of the district as figure 4 shows. The lowest time deviations in public transport accessibility are observed in the central part of Śródmieście, in the southern part of Północ district, the southern part of Zachód district and in the central part of Prawobrzeże district. 
The time deviations observed between 6:00 and $8: 00 \mathrm{pm}$ indicate that they are the highest in the western and south-western part of Prawobrzeże district as well as in the northern part of Północ district. The average time deviations have been recorded in almost entire Zachód district and in the southern part of Północ district. The lowest time deviations in travel times to the cinemas are observed in the central parts of Śródmieście and Prawobrzeże districts.

Time deviations in public transport accessibility to the shopping centres were analysed for the time period starting at 5:00 pm and finishing at 7:00 pm. The highest deviations are observed in the eastern part of Prawobrzeże district and in the northern part of Północ district. In Zachód district the deviations vary from place to place while in Północ district they are highly diversified. The lowest time deviations in public transport accessibility to the shopping centres have been recorded in the central parts of Śródmieście and Prawobrzeże districts and in the southern part of Zachód district (Fig. 4).

Time deviations in public transport accessibility to the hospitals were analysed for the time period starting at 7:00 am and finishing at 9:00 am. The highest deviations are observed in the eastern part of Prawobrzeże district and in the northern part of Północ district. Small time deviations have been recorder in the northern and central part of Prawobrzeże and in the southern part of Północ district as well as in almost entire Zachód district. The smallest deviations are observed in the central part of Śródmieście district (Fig. 4).

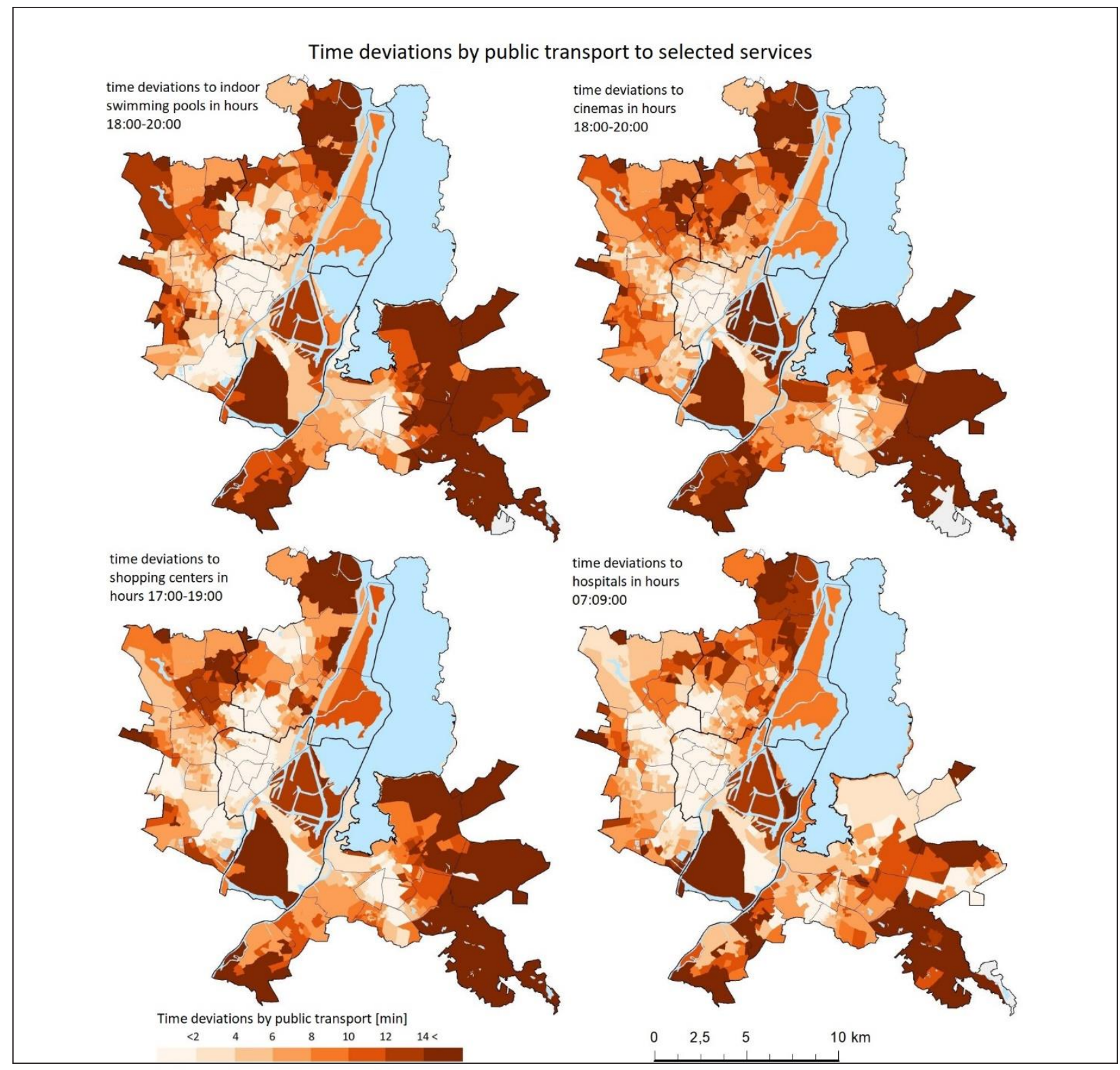

Fig. 4. Average deviations of travel time by public transport to the selected service.

Source: own elaboration. 
The largest percentage of people live in the area of the lowest time deviation in accessibility to the shopping centres. A slightly smaller group has good accessibility - with relatively low time deviations - to the hospitals and indoor swimming pools. The highest time deviations have been recorded in time accessibility to the cinemas. To sum up, the analysis has shown that $80-90 \%$ of Szczecin citizens live in areas where maximum time deviations are 8 minutes, no matter the service chosen (Fig. 5). others point out that calculations made for 15 minute intervals may be burdened with errors. Therefore, according to them, time intervals shall be chosen randomly in order to avoid a situation when travel time is calculated just after a particular means of transport has just left. The author of this article agrees with $M$. Stępniak's et al., (2019) opinion, still he thinks that using 9 profiles of time accessibility with 15 minute intervals allows to grasp time deviations quite accurately and properly. It can be confirmed by the study

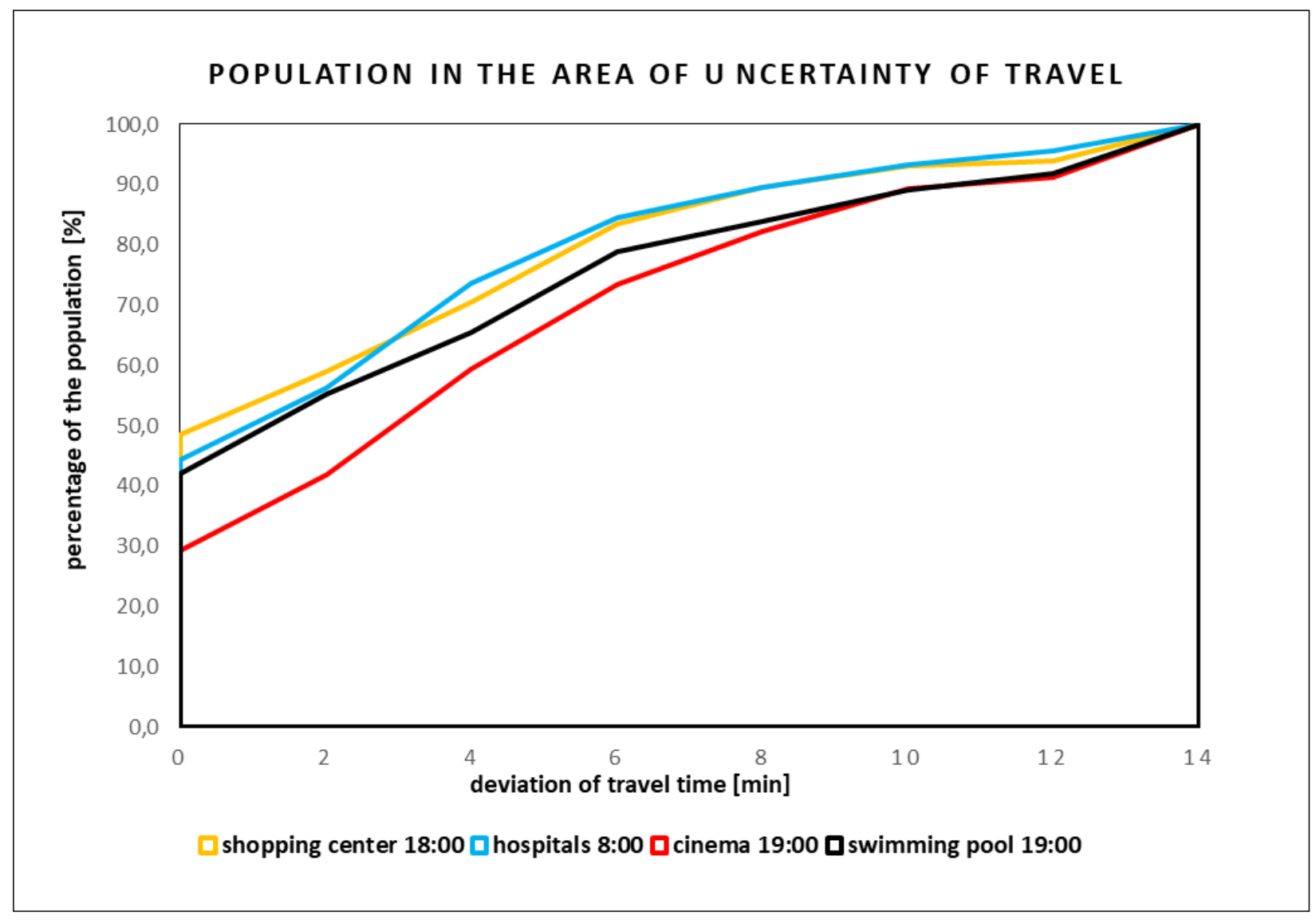

Fig. 5. The population is exposed to a large diversity of travel time.

Source: own elaboration.

\section{Conclusions}

Travel times to service facilities depends on several factors. The most significant one, shaping travel duration, is obviously physical distance between a travel source and a chosen place of destination. Another vital factor is a particular means of transport. In this paper only means of public transport were analysed. Buses, trams or underground trains run according to timetables thus, there are particular time intervals of their operations. Another important thing is to know how much time it takes passengers to get to a particular stop or station (Wessel, Widener, 2016). In their article published in M. Stępniak et al. (2019) and by S. Goliszek and M. Połom (2016b) in which 5 minute intervals were analysed and the time deviations appeared to be very similar to the ones calculated in this study. It is also an interesting finding that some services are not located in densely populated areas (Goliszek, 2017b). The author of this paper is aware that a person living near a low-frequency stop usually checks the timetable and leaves home at a particular time while passengers living near the city centre, where there are high-frequency stops, do not have to do this and can leave any time with low probability of long waiting time. 
ORCID

Sławomir Goliszek https://orcid.org/0000-0003-0908-1487

\section{Acknowledgements}

The article was created on the basis of the project: "Significance of transport accessibility components in Szczecin with particular focus on collective transport in the period of 2009-2018 (TraCoM)", financed from the resources of the National Science Center granted on the basis of Decision No. UMO-2017/25/N/ HS4/01237.

\section{References}

Allen J., 2018, Using Network Segments in the Visualization of Urban Isochrones, Cartographica The International Journal for Geographic Information and Geovisualization, 53(4), 262-270.

Allen J., 2019, Mapping differences in access to public libraries by travel mode and time of day, Library \& Information Science Research, 41, 11-18.

Allen J., Farber S., 2019, Sizing up transport poverty: A national scale accounting of low-income households suffering from inaccessibility in Canada, and what to do about it., Transport Policy, 74, 214-223.

Beister M., Górny J., Połom M., 2015, Rozwój infrastruktury tramwajowej w Polsce w okresie członkostwa w Unii Europejskiej, Technika Transportu Szynowego, 7-8, 24-40.

Bul R., Resiński T., 2014, Wpływ funduszy europejskich na funkcjonowanie i rozwój kolei regionalnych w centralnej części województwa wielkopolskiego w latach 2006-2014, Transport Miejski i Regionalny, 6, 32-40.

Burdziej J., 2016, Analiza dostępności przestrzennej za pomocą technologii GIS na przykładzie obiektów użyteczności publicznej w Toruniu, Prace Komisji Geografii Komunikacji PTG, 19(1), 43-51.

Chojnicki Z., 1966, Zastosowanie modeli grawitacji i potencjału w badaniach przestrzenno-ekonomicznych, Studia KPZK PAN, 14.

Delmelle E. C., Casas I., 2012, Evaluating the spatial equity of bus rapid transit-based accessibility patterns in a developing country: The case of Cali, Colombia, Transport Policy, 20, 36-46.

El-Geneidy A., Buliung R., Diab E., 2015, Non-stop equity: Assessing daily intersections between transit accessibility and social disparity across the Greater Toronto and Hamilton Area (GTHA). Environment and Planning B: Planning and Design, 43(3), 540-560.

El-Geneidy A., Levinson D., Diab E., Boisjoly G., Verbich D., Loong C., 2016, The cost of equity: Assessing transit accessibility and social disparity using total travel cost, Transportation Research Part A: Policy and Practice, 91, 302-316.
Farber S., Morang M. Z., Widener M. J., 2014, Temporal variability in transit-based accessibility to supermarkets. Applied Geography, 53, 149-159.

Gadziński J., 2018, Perspectives of the use of smartphones in travel behaviour studies: Findings from a literature review and a pilot study, Transportation Research Part C: Emerging Technologies, 88, pp. 74-86.

Gadziński J., Radzimski A., 2015, The first rapid tramline in Poland: How has it affected travel behaviours, housing choices and satisfaction, and apartment prices?, Journal of Transport Geography, 54, 451-463.

Galton F., 1881, On the construction of isochronic passage charts, Proceedings of the Royal Geographical Society, 3 , 657-658.

Geurs K. T., Ritsema van Eck J., 2001, Accessibility Measures: Review and Applications, Evaluation of Accessibility Impacts of Land-Use Transportation Scenarios, and Related Social and Economic Impact, vol, 787, National Institute of Public Health and the Environment, Bilthoven.

Geurs K. T., van Wee B., 2004, Accessibility evaluation of land-use and transport strategies: review and research directions, Journal of Transport Geography, 12(2), 127140.

Goch K., Ochota S., Piotrkowska M,. Kunert Z., 2018, Measuring dynamic public transit accessibility to local centres in Warsaw, Urban Development Issues, 58 (1), 29-40.

Goliszek S., 2014a, Dostępność komunikacyjna transportem zbiorowym w Białymstoku - wpływ środków z perspektywy UE na lata 2014-2020, Transport Miejski i Regionalny, 11, 19-26.

Goliszek S., 2014b, Poprawa dostępności miejskim transportem zbiorowym w Olsztynie w świetle inwestycji infrastrukturalnych z perspektywy UE 2014-2020, Transport Miejski i Regionalny, 5, 30-36.

Goliszek S., 2017a, Space-time variation of accessibility to jobs by public transport - a case study of Szczecin, EUROPA XXI, 33, 49-66.

Goliszek S., 2017b, Udział transportu zbiorowego w poprawie dostępności do usług w Gdyni, Prace Komisji Geografii Komunikacji PTG, 20(1), 36-49.

Goliszek S., 2018, Identyfikacja transportowego i przestrzennego komponentu dostępności komunikacyjnej w wybranych nadmorskich ośrodkach miejskich, Prace Komisji Geografii Komunikacji PTG, 21(2), 7-16.

Goliszek S., Połom M., 2016a, Porównanie dostępności komunikacyjnej transportem zbiorowym w ośrodkach wojewódzkich Polski Wschodniej na koniec perspektywy UE 2007-2013, Transport Miejski i Regionalny, 3, 16-27.

Goliszek S., Połom M., 2016b, The use of general transit feed specification (GTFS) application to identify deviations in the operation of public transport at morning rush hour on the example of Szczecin, EUROPA XXI, 31, 51-60.

Goliszek S., Połom M., 2016c, Wpływ budowy nowej linii tramwajowej w Olsztynie na zmianę dostępności 
transportem zbiorowym, Acta Scientarum Polonorum Administratio Locorum, 15(3), 19-34.

Goliszek S., Rogalski M., 2014, Przestrzenno-czasowe zmiany dostępności komunikacyjnej miejskim transportem w Rzeszowie w świetle inwestycji współfinansowanych ze środków UE 2014-2020, Transport Miejski i Regionalny, 7, 23-30.

GTFS open data Szczecin, https://www.zditm.szczecin.pl/ rozklady/GTFS/latest/ [21.03.2019]

Hansen W. G., 1959, How Accessibility Shapes Land-use, Journal of the American Institute of Planners, 25, 73-76.

Ingram D. R., 1971, The Concept of Accessibility: a Search for an Operational Form, Regional Studies, 5, 101-107.

Isard W., 1954, Location Theory and Trade Theory: ShortRun Analysis, Quarterly Journal of Economics, 68(1), 305-322.

Jurkowski W., 2018, Integracja głównych dworców autobusowych i kolejowych w miastach wojewódzkich w Polsce, Przegląd Komunikacyjny, 73(5), 22-26.

Kołoś A., 2007, Fundusze europejskie jako czynnik rozwoju miejskiego transportu szynowego w Polsce - w aglomeracjach do 500 tys. mieszkańców, [in:] J. Kitowski (eds.), Prace Komisji Geografii Komunikacji PTG, XIII, 253-268.

Kołoś A., Taczanowski J., 2016a, The feasibility of introducing light rail systems in medium-sized towns in Central Europe, Journal of Transport Geography, 54, 400-413.

Kołoś A., Taczanowski J., 2016b, Fundusze europejskie jako czynnik rozwoju miejskiego transportu szynowego w Polsce, Prace Komisji Geografii Komunikacji PTG, 19(1), 9-20.

Korczyński K., 2019, Spatial accessibility to public transport in a medium sized city using the example of Sanok, Przegląd Komunikacyjny, 4, 19-27.

Kubijowicz W., 1923, Izochrony Polski południowej, Prace Instytutu Geograficznego UJ, 1, 96.

Martínez-Jiménez E., Salinas-Pérez J. A., 2019, Accessibility to culture and education. Educative city of Córdoba (Spain). Journal of Maps, 15(1), 39-45.

Neutens T., 2015, Accessibility, equity and health care: review and research directions for transport geographers, Journal of Transport Geography, 43, 14-27.

OpenStreetMap, https://www.geofabrik.de/data/download.html [21.03.2019]
Podoski J., 1977, Transport w miastach, Wydawnictwa Komunikacji i Łączności, Warszawa.

Poelman H., Dijkstra L., 2015 Measuring access to public transport in European cities. Regional Working Paper. Regional and Urban Policy.

Radzimski A., Gadziński J., 2019, Travel Behaviour In A PostSocialist City, European Spatial Research and Policy, 26(1), 43-60.

Salonen M., Toivonen T., 2013, Modelling travel time in urban networks: comparable measures for private car and public transport, Journal of transport Geography, 31, 143-153.

Stępniak M., Goliszek S., 2017, Spatio-temporal variation of accessibility by public transport - the equity perspective [in:] I. Ivan, A. Singleton, J. Horák, T. Inspektor (eds.), The rise of big spatial data, Lecture Notes in Geoinformation and Cartography, Springer International Publishing, Cham, s. 241-261.

Stępniak M., Pritchard J., Geurs K., Goliszek S., 2019, The impact of temporal resolution on public transport accessibility measurement: Review and case study in Poland, Journal of Transport Geography, 75(2), 8-24.

Vasiliev I.R., 1997, Mapping Time. Cartographica, 34, 3, Series Monograph, 49, 1-51.

Wessel N., Allen J., Farber, S., 2017, Constructing a Routable Retrospective Transit Timetable from a Real-time Vehicle Location Feed and GTFS. Journal of Transport Geography, 62, 92-97.

Wessel N., Widener M., 2016, Discovering the space-time dimensions of schedule padding and delay from GTFS and real-time transit data. Journal of Geographical Systems, 19(1), 93-107.

Widener M., Minaker L., Farber S., Allen J., Vitali B., Coleman P. C., Cook B., 2017, How do changes in the daily food and transportation environments affect grocery store accessibility?, Applied geography, 83, 46-62.

Zalewska A., 2016, Wpływ środków Unii Europejskiej na rozwój transportu zbiorowego w Lublinie, Transport Miejski i Regionalny, 4, 11-18. 